\title{
MEASURING AND EXPLAINING THE DEVELOPMENT OF THE CIVIL SOCIETY SECTOR
}

Primož PEVCIN

Faculty of Administration, Liubliana

UDK: 321.72

Izvorni znanstveni rad

Primljeno: 7. 9. 2011.

Recent decades have seen a substantial increase in the socio-economic importance of the civil society sector. Nowadays the sector tends to be seen as one of the pre-requisites of socio-economic development of a society. Nevertheless, comparisons of existing international data reveal substantial variations in the development and socio-economic importance of the sector. The paper presents three alternative measurements of the development of the civil society sector which tend to be described in the form of various civil society indexes. The results indicate that alternative measurements of sector development tend to be positively related, although the strength and significance of particular relationships differ substantially. Furthermore, the ability to empirically explain international variations in the development of the sector through various theoretically plausible economic, political, social and cultural explanatory variables is subject to the selection of particular measurement of sector development, although empirical results tend to suggest that differences in cultural fragmentation and wealth of society seem to be relevant factors regardless of the civil society index being considered.

Keywords: civil society sector, sector labels, civil society indexes, variations, empirical analysis

$\triangle \quad$ Primož Pevcin, University of Ljubljana, Faculty of Administration, Gosarjeva ulica 5, 1000 Ljubljana, Slovenia. E-mail: primoz.pevcin@fu.uni-li.si

\section{INTRODUCTION}

The development of the civil society sector has been increasingly addressed in contemporary literature, a potential reason being the fact that civil society organisations often perform critical socio-economic functions, thereby complementing or 
DRUŠ. ISTRAŽ. ZAGREB GOD. 21 (2012),

BR. $3(117)$

STR. $631-650$

PEVCIN, P.:

MEASURING AND. substituting government and the business sector. Furthermore, the trend of increasing socio-economic importance of the sector has been observed in recent decades. However, substantial variations in the development of the sector among countries can be observed, particularly when investigating existing data on the size and development of the sector. In this context, the study aims to portray the development of the sector in a cross-national perspective. The main purpose of the paper is to empirically investigate which potential economic, social, political and cultural factors, based on theoretical premises, could explain the variations in development of the civil society sector in different countries.

\section{DEFINING THE CIVIL SOCIETY SECTOR}

There exist a number of definitions of civil society (sector). ${ }^{1}$ Anheier et al. (2001) have developed an operational definition of the sector which classifies civil society institutions, organisations and individuals among the concepts of family, government and market, where people associate voluntarily to promote common goals. Civil society holds very different meanings to various stakeholders, such as the space of solidarity, the area of associational life, the third sector, etc. (Chandhoke, 2002). Since this concept identifies various things, numerous alternative labels for defining it are used both in theory and in practice. For instance, this sector is often alternatively labelled as the third sector, the non-profit sector, the social economy (sector), the non-government sector or even as the independent, voluntary or charitable sector (Worth, 2009).

Indeed, Lorentzen (2010) has recognised that four most commonly used labels for the sector are the non-profit, third, voluntary and civil society (sector). He has however admitted that the choice of the sector label seems to be accidental, which means that labels are usually used as synonyms. In particular, Lewis (2010) has summarised that these "over-lapping" labels mainly reflect different cultures and histories in which studies of the sector emerged. Specifically, he has argued that the label "non-profit" tends to be more rigorously used in the United States where the market is dominant, whereas the label "voluntary" tends to be more rigorously used in the United Kingdom where a longer tradition of voluntary work exists due to the development of charity law. Furthermore, Lyons (2009) has argued that it has recently become very popular to use the label "civil society", since this label should have a normative dimension in the sense that it is seen as one of the key pre-requisites of economic and social development. ${ }^{2}$

The civil society sector includes a diverse set of organisations which basically serve common purposes, such as organi- 
DRUŠ. ISTRAŽ. ZAGREB GOD. 21 (2012),

BR. 3 (117)

STR. $631-650$

PEVCIN, P.:

MEASURING AND.. sations in health, arts, culture, education, research, religious services, fund-raising and advocacy activities, etc. Indeed, Salamon (2010) has stressed that civil society organisations nowdays perform several critical functions associated with delivering vital human services, bringing certain problematic issues to public attention and so on. He has argued that the ability to perform those functions is associated with the nature of civil society organisations, such as the prevailing combination of private structure and public purpose, connections to citizens and a generally smaller scale.

\section{DEVELOPMENT AND SOCIO-ECONOMIC IMPORTANCE OF THE CIVIL SOCIETY SECTOR}

Civil society currently represents an important part of the economic, political and social environment in the majority of developed countries. ${ }^{3}$ Existing literature and empirical evidence generally supports the thesis that there has been a substantial growth in the number of civil society organisations in recent decades. Salamon (1994), for instance, who has labelled this process as "associational revolution", has stressed that this growth occurred because the sector increasingly complements the government and markets in the provision of important services, especially in health, education and social fields.

Several attempts have been made so far to measure the size and development of the civil society sector in a cross-country perspective. Anheier et al. (2001), for example, have proposed the Civil Society Index (CSI) as a potential measurement of the size and development of the sector. The methodology of measurement has been based on four dimensions of a diamond: structure, values, space, and impact. Those dimensions are scaled from 0 to 3 for each country, based on the values of the 74 indicators, which are generally grouped in one of the original dimensions (see Civicus, 2006). The collection of data is based on secondary data collection, media analysis, specialist surveys and country-specific consultations. ${ }^{4}$

Another methodology of measuring the size and development of the civil society sector has been proposed by Glasius et al. (2002) in the form of the Global Civil Society Index (GCSI). This approach focuses on three dimensions of civil society: organisational infrastructure, civility of individuals and participation of individuals, although it includes only those dimensions of the sector that go beyond the borders of national economies and/or societies. ${ }^{5}$ The GCSI is basically a composite measurement of separate component indicators, developed for 33 countries, where simple scores for countries tend to range up to 1.5. 
DRUŠ. ISTRAŽ. ZAGREB GOD. 21 (2012) BR. $3(117)$

STR. $631-650$

PEVCIN, P.:

MEASURING AND.

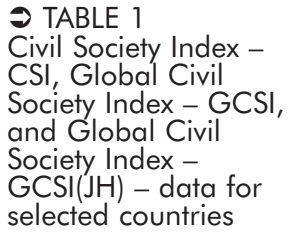

In addition, another study has been performed by the CNP (2004), which has provided data on the size of the non-profit sector for 46 countries. Size and development of the sector have been measured by the share of sector workforce in the economically active population and by the share of sector expenditures in GDP. Subsequently, Salamon and Sokolowski (2004) upgraded that data and developed the Global Civil Society Index ${ }^{6}$ for 34 countries, in which they included three dimensions of the so-called civil society sector: capacity, sustainability, and impact. In this procedure, each country was given a set of 12 numbers (indicators) which were normalised, totalled and averaged to give a single index (score). ${ }^{7}$

\begin{tabular}{lccc}
\hline Country & $\begin{array}{c}\text { CSI } \\
\text { (summarised score) }\end{array}$ & $\begin{array}{c}\text { GCSI } \\
\text { (simple score) }\end{array}$ & $\begin{array}{c}\text { GCSI } \\
\text { (JH) }\end{array}$ \\
\hline Argentina & 6.7 & 0.38 & 40 \\
Czech Republic & 7.6 & 0.80 & 31 \\
Germany & 9.4 & 0.71 & 46 \\
Italy & 8.4 & 0.74 & 33 \\
Netherlands & 8.3 & 1.32 & 74 \\
Poland & 6.8 & 0.38 & 25 \\
Chile & 7.7 & 0.37 & $/$ \\
Croatia & 7 & 0.56 & $/$ \\
Greece & 6.4 & 0.67 & $/$ \\
Russian Fed. & 4.9 & 0.33 & $/$ \\
Slovenia & 6.8 & 0.71 & $/$ \\
Ukraine & 6.6 & 0.33 & $/$ \\
Austria & $/$ & 0.90 & 37 \\
Finland & $/$ & 1.11 & 47 \\
France & $/$ & 0.91 & 49 \\
Hungary & $/$ & 0.34 & 30 \\
Ireland & $/$ & 0.94 & 54 \\
Mexico & $/$ & 0.22 & 24 \\
Slovak Rep. & $/$ & 0.69 & 24 \\
Spain & $/$ & 0.63 & 40 \\
Sweden & $/$ & 1.50 & 60 \\
United Kingdom & 5.6 & 0.83 & 58 \\
United States & 7.6 & 0.71 & 61 \\
India & & $/$ & 26 \\
Romania & 5.4 & 22 \\
South Korea & & & 35 \\
& & & \\
\hline
\end{tabular}

Sources: Civicus (2006), Glasius et al. (2002), Salamon and Sokolowski (2004).

Table 1 indicates that substantial differences exist in the development and relative socio-economic importance of the sector among countries, although two comments should be added. First, the main limitation of existing studies is that they 
DRUŠ. ISTRAŽ. ZAGREB GOD. 21 (2012), BR. 3 (117)

STR. $631-650$

PEVCIN, P.: MEASURING AND... tend to be performed only for selected groups of countries, which subsequently limits the possibility of comprehensive international comparisons. For example, the data presented in Table 1 indicates that the data on all three measurements of sector size are available only for a very small number of countries. ${ }^{8}$ Second, data comparisons may reveal that some discrepancies exist in the perceived development of the sector as observed for different measurements of sector development since for some countries the values of one index are relatively greater compared to values of other index(es). ${ }^{9}$ However, bivariate Pearson correlation coefficients between different measurements of sector development indicate that those measurements are all positively related. Interestingly, the strongest (and statistically most significant) relationship is between the GCSI(JH) and GCSI indexes. ${ }^{10}$ This means that the development of domestic and international aspects of the sector may be highly related, in particular in the context of more developed countries for which data collection predominantly overlaps. Besides, this somehow indicates that different measurements could be taken as "correct", as they should measure the same thing, although we should be aware that individual discrepancies between indexes exist, which is especially true for the GCSI index. ${ }^{11}$

\section{RESEARCH OF VARIATIONS IN THE DEVELOPMENT OF THE CIVIL SOCIETY SECTOR}

Theories on the factors affecting the development of the civil society sector are multidisciplinary in their nature. For instance, one of the most influential approaches are the so-called failure theories which state that development of the sector depends on the extent of market failure, contract failure and government failure (Young, 1998). According to the market failure argument, the need for the civil society sector emerges in order to offset transaction costs, a typical example being the costs of pooling resources to achieve common goals. Similarly, the contract failure argument supplements the idea of the market failure argument in case of complex goods (i.e., higher education, medical services, etc.), where consumers are unable to competently evaluate the quality and quantity of services they are receiving. ${ }^{12}$

Finally, the government failure argument contemplates that the need for the civil society sector emerges when governments fail to correct market failures, thereby creating space for civil society organisations to fulfil unsatisfied needs. This should be particularly relevant for diverse societies since government usually responds to the needs and demands of the majority. This argument has been thoroughly addressed by a- 
DRUŠ. ISTRAŽ. ZAGREB GOD. 21 (2012)

BR. $3(117)$

STR. $631-650$

PEVCIN, P.:

MEASURING AND. nother very influential approach called the heterogeneity theory (see Weisbrod, 1988), which argues that the development and socio-economic importance of civil society depends on the level of heterogeneity observed in a particular society. Namely, heterogeneity causes differences in the preferences and needs of citizens, thereby causing greater demand for "public" goods and services with more individualistic and pluralistic characteristics which tend to be provided by civil society organisations. ${ }^{13}$

A further two very influential approaches are the theories of interdependence and resource dependence. The interdependence theory, for instance, initiated by Salamon (1987), argues that the government provides substantial financial resources to civil society organisations which in turn deliver certain goods and services instead of the government. ${ }^{14}$ In contrast, the resource dependence approach, initiated by Pfeffer and Salancik (1978), actually argues that resources available to the civil society sector depend on the wealth of a certain society (as the prerequisite for the ability to contribute funds), as well as the amount of government spending (as one of the most important revenue sources for such organisations). ${ }^{15}$

\section{RESEARCH DESIGN AND DATA DESCRIPTION}

There is a marked lack of studies that focus on the determinants of cross-country variations in the size of the civil society sector. ${ }^{16}$ Furthermore, there is also a lack of studies that try to use different measurements of the size and development of the sector. This paper attempts to use various existing measurements of sector size with the purpose of empirically verifying the effect of potential factors that may cause variations in the size of the sector among countries. The approach adopted for this study is to combine the experience of existing studies and development of cross-section econometric models in which the size of the sector attempts to be explained with relevant economic, social, cultural and political factors. Due to the use of different measurements of sector size, analyses are performed in different sets of countries depending on the availability of data. ${ }^{17}$

Empirical analyses are performed using three different measurements of the size of the sector; the Global Civil Society Index - GCSI(JH), obtained from Salamon and Sokolowski (2004); the Civil Society Index - CSI, obtained from Civicus (2006); and the Global Civil Society Index - GCSI, obtained from Glasius et al. (2002). ${ }^{18}$ Descriptive statistics of dependent variables show that the mean value of the Global Civil Society Index GCSI(JH) is approximately 40 , with the Netherlands ha- 
DRUŠ. ISTRAŽ. ZAGREB GOD. 21 (2012), BR. 3 (117),

STR. $631-650$

PEVCIN, P.: MEASURING AND... ving the maximum value in the sample at 74 and Pakistan having the minimum value at 19.19 The mean value of the summed-up Civil Society Index CSI is approximately 6.3, with Germany having the maximum value in the sample at 9.4 and Togo having the minimum value at 3.9.20 Finally, the mean value of the simple Global Civil Society Index GCSI score is approximately 0.72 , with Sweden having the maximum value in the sample at 1.50 and Mexico having the minimum value at $0.22 .{ }^{21}$

Several economic, social, cultural and political variables are used as the explanatory variables; the main approaches evaluated in the study are the heterogeneity of supply and demand, the resource dependence theory, the interdependence theory and failure theories. The first explanatory variable describes the supply-side heterogeneity of society, which could be measured with the level of income inequality. The introduction of this single variable, which should serve as a proxy for supply-side heterogeneity, has been suggested also by Corbin (1999). The second explanatory variable describes the level of the democratic development of the society, which should attempt to explain the notion that the socio-economic importance of the sector is the result of democracy. The third explanatory variable relates to the resource dependence hypothesis, which contemplates that the development of the sector is related to the availability of resources; in wealthier societies the sector should be greater. The single most appropriate variable to describe the wealth of society seems to be gross domestic product per capita since it also captures relative aspects of wealth and data is usually internationally comparable. The fourth explanatory variable relates to interdependence hypotheses. This variable sets the size of government transfer expenditures as a proxy for identifying the effect of governmental welfare related spending. The study wishes to verify whether this spending promotes or crowds out (social) activities of the civil society sector. Indeed, the social activities of the government can be best observed through transfer expenditures. The fifth explanatory variable should validate the market failure argument, i.e. whether market failures affect the size of the civil society sector. For this purpose the extent of poverty is taken as a proxy for describing the existence of market failures. Greater poverty in society should potentially identify existing market failures. ${ }^{22}$

Finally, three explanatory variables describing ethnic, linguistic and religious fragmentation of society are used in order to test the demand heterogeneity argument. ${ }^{23}$ Descriptions of variables and data sources are presented in Table 2. 


\begin{tabular}{|c|c|c|}
\hline Variable & Description & Source \\
\hline $\begin{array}{l}\text { Income } \\
\text { inequality }\end{array}$ & $\begin{array}{l}\text { Gini Index - the extent to which distribution } \\
\text { of income between individuals and house- } \\
\text { holds in a society deviates from a perfectly } \\
\text { equal distribution }\end{array}$ & $\begin{array}{l}\text { United Nations (2009); } \\
\text { Glasius et al. (2002) }\end{array}$ \\
\hline Democracy & $\begin{array}{l}\text { Index of democracy - index measures demo- } \\
\text { cracy through competition and participation } \\
\text { (greater index value denotes greater } \\
\text { democracy) }{ }^{25}\end{array}$ & $\begin{array}{l}\text { Vanhanen (2000) - } \\
\text { dataset version } 2.0\end{array}$ \\
\hline Wealth & $\begin{array}{l}\text { Gross domestic product per capita in 1,000 } \\
\text { purchasing power parity USD } 26\end{array}$ & $\begin{array}{l}\text { Freedom House (2002); } \\
\text { Glasius et al. (2002) }\end{array}$ \\
\hline Transfers & Governmental transfer expenditures in GDP & Gwartney and Lawson (2009) \\
\hline Poverty & $\begin{array}{l}\text { Head Count Index - percentage of population } \\
\text { below national poverty line }{ }^{27}\end{array}$ & CIA (2010) \\
\hline $\begin{array}{l}\text { Ethnic, } \\
\text { linguistic, } \\
\text { and religious } \\
\text { fragmentation }\end{array}$ & $\begin{array}{l}\text { Indexes of ethnic, linguistic and religious } \\
\text { fragmentation of society - computed as one } \\
\text { minus the Herfindahl index of ethnic, linguistic } \\
\text { or religious group shares } 28\end{array}$ & Alesina et al. (2003) \\
\hline $\begin{array}{l}\text { Openness } \\
\text { of society }\end{array}$ & $\begin{array}{l}\text { Total trade (sum of the market value of imports } \\
\text { and exports of goods and services) in } \% \text { of GDP }\end{array}$ & World Bank (2001) \\
\hline
\end{tabular}

(1) TABLE 2

Description of variables and data sources $^{24}$
Basically, the econometric analysis attempts to test the following three main hypotheses:

- H1: The modelling of determinants causing variations in the size of the civil society sector among countries should be more difficult if the CSI index is used as a dependent variable. This should occur due to the fact that CSI includes the most diverse set of countries.

- H2: The different dependent variables (indexes) also affect factors that shape differences in the size of the sector among countries. Different indexes measure different aspects of sector size which can be observed in the discrepancies in observed sector development in a particular country.

- H3: The most important factor affecting the development of the sector is related to resource availability, in particular the wealth of a society. It is therefore expected that resource availability should be the most important determinant of sector operation since resources represent the basis for the organisation of activities. 


\section{EMPIRICAL RESEARCH - MAIN FINDINGS AND DISCUSSION}

\begin{tabular}{|c|c|c|c|c|}
\hline \multirow{10}{*}{$\begin{array}{l}\text { TABLE } 3 \\
\text { Zero-order correlations } \\
\text { between measure- } \\
\text { ments of the develop- } \\
\text { ment of the civil } \\
\text { society sector and } \\
\text { explanatory } \\
\text { variables } 29\end{array}$} & \multicolumn{4}{|c|}{$\begin{array}{l}\text { Correlation coefficients between dependent and explanatory } \\
\text { variables are presented in Table } 3 \text {. The strongest (and also high- } \\
\text { ly statistically significant) relationship is between the wealth } \\
\text { of society and the development of the civil society sector. This } \\
\text { relationship is also positive according to theoretical expecta- } \\
\text { tions. Similarly, the relationship between democracy and de- } \\
\text { velopment of the civil society sector is also positive, rather } \\
\text { strong and statistically significant in all cases, supporting the } \\
\text { idea that development of the civil society sector is the result } \\
\text { of the democratic development of society. Similarly, the rela- } \\
\text { tionship between governmental transfer spending and deve- } \\
\text { lopment of the civil society sector is also rather strong, posi- } \\
\text { tive and statistically significant, supporting the idea that the } \\
\text { civil society sector obviously supplements government in so- } \\
\text { cial and welfare policy implementation. In contrast, the rela- } \\
\text { tionship between income inequality and development of the } \\
\text { civil society sector is negative in all cases, although this relation- } \\
\text { ship tends to be rather weak, but provides an argument for } \\
\text { the notion that social cohesion is associated with a better de- } \\
\text { veloped civil society sector. With regard to the variables descri- } \\
\text { bing demand side heterogeneity, it appears that the relation- } \\
\text { ship between those variables and the development of the civil } \\
\text { society sector is rather weak. Besides, this relationship does } \\
\text { not follow theoretical predictions in the majority of cases. Fi- } \\
\text { nally, the relationship between poverty and civil society sec- } \\
\text { tor size is negative and statistically significant, indicating that } \\
\text { a less developed civil society sector is obviously associated } \\
\text { with greater poverty. }\end{array}$} \\
\hline & & GCSI $(J H)$ & CSI & GCSI 30 \\
\hline & Income inequality & $\begin{array}{l}-0.277 \\
(0.062)\end{array}$ & $\begin{array}{l}-0.220 \\
(0.105)\end{array}$ & $\begin{array}{l}-0.439 \\
(0.005)\end{array}$ \\
\hline & Democracy & $\begin{array}{c}0.555 \\
(0.000)\end{array}$ & $\begin{array}{c}0.585 \\
(0.000)\end{array}$ & \\
\hline & Wealth & $\begin{array}{c}0.813 \\
(0.000)\end{array}$ & $\begin{array}{c}0.686 \\
(0.000)\end{array}$ & $\begin{array}{c}0.757 \\
(0.000)\end{array}$ \\
\hline & Transfers & $\begin{array}{c}0.497 \\
(0.002)\end{array}$ & $\begin{array}{c}0.627 \\
(0.000)\end{array}$ & $\begin{array}{c}0.436 \\
(0.006)\end{array}$ \\
\hline & Ethnic fragmentation & $\begin{array}{l}-0.369 \\
(0.019)\end{array}$ & $\begin{array}{l}-0.302 \\
(0.034)\end{array}$ & $\begin{array}{l}-0.326 \\
(0.019)\end{array}$ \\
\hline & Linguistic fragmentation & $\begin{array}{l}-0.098 \\
(0.297)\end{array}$ & $\begin{array}{l}-0.257 \\
(0.062)\end{array}$ & $\begin{array}{c}0.046 \\
(0.400)\end{array}$ \\
\hline & Religious fragmentation & $\begin{array}{c}0.177 \\
(0.166)\end{array}$ & $\begin{array}{c}0.131 \\
(0.220)\end{array}$ & $\begin{array}{l}-0.214 \\
(0.116)\end{array}$ \\
\hline & Poverty & $\begin{array}{l}-0.452 \\
(0.012)\end{array}$ & $\begin{array}{l}-0.179 \\
(0.151)\end{array}$ & $\begin{array}{c}-0.395 \\
(0.023)\end{array}$ \\
\hline
\end{tabular}


DRUŠ. ISTRAŽ. ZAGREB GOD. 21 (2012) BR. $3(117)$

STR. $631-650$

PEVCIN, P.:

MEASURING AND..

(1) TABLE 4

Factors affecting variations in the development of the civil society sector ${ }^{33}$
Results of a regression analysis investigating potential factors that cause differences in the development of the civil society sector are presented in Table 4 . It is worth noting that the results of the analysis, related also to the effect of different explanatory variables, substantially differ if different measurements of the development of civil society sector are used. For instance, the use of the GCSI $(\mathrm{JH})$ index (model 1) or GCSI index (model 3) to measure the development of the sector means that almost four fifths of the variance in the sector development among countries could be explained. ${ }^{31}$ In contrast, the modelling of the variations in sector development is much more difficult if the CSI index is used as the dependent variable. In this case, only about one third of the variance could be explained. ${ }^{32}$ Interestingly, this supports the propositions of hypothesis 1 as stated earlier.

\begin{tabular}{|c|c|c|c|}
\hline Explanatory & $\begin{array}{l}\text { GCSI }(J H) \\
\text { (Model 1) }\end{array}$ & $\begin{array}{l}\text { CSI } \\
\text { (Model 2) }\end{array}$ & $\begin{array}{l}\text { GCSI } 34 \\
\text { (Model 3) }\end{array}$ \\
\hline Intercept & $\begin{array}{l}2.3878 \\
(0.1607,14.855)^{* * *}\end{array}$ & $\begin{array}{l}1.4261 \\
(0.1260,11.322)^{* * *}\end{array}$ & $\begin{array}{l}-2.31 \\
(0.5017,-4.621)^{* * *}\end{array}$ \\
\hline Income inequality & $\begin{array}{l}0.0135 \\
(0.0037,3.609)^{* * *}\end{array}$ & / & / \\
\hline Democracy & / & / & $\begin{array}{l}0.0115 \\
(0.0051,2.269)^{* *}\end{array}$ \\
\hline Wealth & $\begin{array}{l}0.0380 \\
(0.0031,12.083)^{* * *}\end{array}$ & $\begin{array}{l}0.0170 \\
(0.0072,2.380)^{* *}\end{array}$ & $\begin{array}{l}0.5632 \\
(0.0666,8.449)^{* * *}\end{array}$ \\
\hline Transfers & $\begin{array}{l}0.0236 \\
(0.0148,1.595)\end{array}$ & $\begin{array}{l}0.0079 \\
(0.0048,1.657)\end{array}$ & / \\
\hline Ethnic fragmentation & $\begin{array}{l}-0.2530 \\
(0.1901,-1.331)\end{array}$ & $\begin{array}{l}0.342 \\
(0.196,1.743)^{*}\end{array}$ & $\begin{array}{l}-0.2292 \\
(0.0867,-2.644)^{* *}\end{array}$ \\
\hline Linguistic fragmentation & $\begin{array}{l}0.4329 \\
(0.1222,3.540)^{* * *}\end{array}$ & $\begin{array}{l}-0.250 \\
(0.165,-1.519)\end{array}$ & $\begin{array}{l}0.1427 \\
(0.0706,2.020)^{*}\end{array}$ \\
\hline Religious fragmentation & / & $\begin{array}{l}0.148 \\
(0.137,1.080)\end{array}$ & / \\
\hline Poverty & / & $\begin{array}{l}0.0035 \\
(0.0026,1.369)\end{array}$ & / \\
\hline $\mathrm{N}$ & 32 & 36 & 33 \\
\hline $\mathrm{R}^{2}$ adj. & 0.7803 & 0.3587 & 0.7952 \\
\hline SEE & 0.169 & 0.1567 & 0.2338 \\
\hline Durbin-Watson d & 1.88 & 2.02 & 2.33 \\
\hline F-stat $(p)$ & $23.02(0.000)$ & $3.61(0.012)$ & $25.85(0.000)$ \\
\hline $\operatorname{RESET}(p)$ & 0.891 & 0.976 & 0.732 \\
\hline
\end{tabular}


DRUŠ. ISTRAŽ. ZAGREB GOD. 21 (2012), BR. 3 (117)

STR. $631-650$

PEVCIN, P.: MEASURING AND... ferently, if different dependent variables are used. In model 2 in particular, where CSI is used as the dependent variable, only two included explanatory variables (out of six) are statistically significant (wealth and ethnic fragmentation) and beta coefficient calculations reveal that the latter variable is the most important one. These two covariates strongly support the validity of the arguments of resource dependence and demand heterogeneity (government failure) theories. It is also the only model in which religious fragmentation and poverty appear as explanatory variables. These two covariates positively affect sector size, which is in line with theoretical predictions (demand heterogeneity and market failure arguments), yet the effect is not statistically significant.

In contrast, in the use of GCSI(JH) as the dependent variable, five explanatory variables tend to explain roughly 78 percent of the variance in sector size among countries included in the analysis. Three of the variables (income inequality, wealth and linguistic fragmentation) are highly statistically significant, meaning that the validity of the arguments of demand heterogeneity (government failure) and resource dependence theories could again be supported, but not the validity of supply side heterogeneity, as the regression coefficient of income inequality is positive. The effect of government transfer expenditures on the development of the sector is again positive which is in line with theoretical predictions, although the effect is not statistically significant, meaning that the validity of the interdependence argument could not be reasonably supported.

Finally, in the use of the GCSI index as the dependent variable, roughly 80 percent of variation in sector size could be explained with five explanatory variables, all of which tend to be statistically significant. The validity of the resource dependence could be validated again, however, the validity of the demand heterogeneity argument is inconclusive since linguistic fragmentation positively affects variations in the development of the sector while ethnic fragmentation affects them negatively. ${ }^{35}$ Although the magnitude of covariates differs substantially, all three models seem to commonly support the validity of demand heterogeneity (government failure) and resource dependence hypotheses, so hypothesis 2 could be rejected.

Particularly notable is the effect of the variable describing wealth of the society, which is the most important explanatory variable in the first and third models (according to beta coefficient values) and a highly statistically significant one in model two. This indicates that supply-side factors such as the availability of resources to the sector seem to be very important in explaining cross-country differences in the develop- 
DRUŠ. ISTRAŽ. ZAGREB GOD. 21 (2012)

BR. $3(117)$

STR. $631-650$

PEVCIN, P.:

MEASURING AND.

\section{CONCLUSION}

\section{NOTES}

ment of the civil society sector, thus also strengthening the notion that the socio-economic importance of the sector is related to the economic development of the society and supports the third hypothesis stated earlier.

Nonetheless, the great diversity of countries under consideration should be taken into account, being especially true for CSI data. This means that obtained results should be considered with due caution. Two possible solutions exist to overcome this problem. The first one is related to a possible narrowing or grouping of the sample to more similar countries. This would, however, cause problems related to sample size in regression analysis since the focus in all three models is on slightly more than 30 countries, which is close to the minimum required sample for statistically relevant results. ${ }^{36}$ The second solution is the possibility of utilizing pooled data, yet the time dimension of all such indexes is non-existing. Consequentially, further collection of data on the development of the sector over different years (periods) is strongly recommended for all three indexes.

The main purpose of the study presented in the paper is to compare different measurements of the development of the civil society sector and to empirically verify the effect of potential factors causing cross-country variations in the development of the sector. All the existing measurements of sector development tend to be positively correlated, indicating that they tend to measure (or better yet, evaluate) certain common aspects of the sector. However, large differences arose when variations in the development of the sector were attempted to be modelled, since the selection of the dependent variable significantly affects the results. Although samples of considered countries are quite diverse, empirical research has found reasonable support for the validity of the theories of government failure (demand heterogeneity) and resource dependence when describing variations in the development of the civil society sector among various countries.

${ }^{1}$ Label civil society sector has been predominantly advocated by Salamon (2010).

${ }^{2}$ He has even argued that this equalisation happened due to changing interests of the public and research funders, which preferred financing the research on "popular" concepts of social capital, democracy and good governance, which are all closely related to civil society.

3 Salamon et al. (2007) have reported that these organisations should, on average, account for approximately $5 \%$ of GDP. 
DRUŠ. ISTRAŽ. ZAGREB GOD. 21 (2012),

BR. $3(117)$

STR. $631-650$

PEVCIN, P.: MEASURING AND..
4 Data for 54 countries/regions has been collected in the 2003-2005 implementation phase of the project. This study summarised the data for four original dimensions in order to receive a single score for each country (see also Table 1). This means that the scores for a particular country may range from 0 to 12 .

5 This index actually measures the global civil society as a transnational or global phenomenon, although this notion is still not very well established in theory and practice. For instance, Taylor (2002) has argued that we cannot talk about a global civil society if we do not have a global state, as without the global state there is only a limited resource infrastructure to support organisations of global civil society.

${ }^{6}$ In this study this index is labelled as GCSI(JH) index in order to avoid confusion with the GCSI index of Glasius et al. (2002). Actually, JH stands for the Johns Hopkins University, since the data used for the creation of the index was taken from the results of a Johns Hopkins University CNP project.

7 Several authors have acknowledged that certain limitations to such a measurement do exist. For instance, Lyons (2009) has argued that GCSI(JH) measures only associational life, but does not measure the other two dimensions of the sector, that is, good society and public sphere, although it is formally more rigorous than CSI. In contrast, CSI is broader, but relies more on the judgements of groups of individuals potentially having knowledge of the state of the sector in a particular country. Moreover, CSI groups indicators into four original dimensions, which means that the obtained values are not expressed in one single number but rather in a "diamond", which actually represents the main value of CSI index. Nonetheless, bivariate correlation coefficients indicate that in the sample of countries under consideration, all four dimensions are positively related (the strongest relationship is between values and space, $r=0.69$, and between space and impact, $r=0.59$ ), which means that it is not inappropriate, for the purpose of the study, to summarise those scores in one single number.

${ }^{8}$ For instance, it can be observed that CSI focuses primarily on less developed countries (developed countries may appear in the analysis more as a benchmark), whereas GCSI, on the other hand, focuses primarily on more prosperous and economically developed countries.

9 See, e.g., relative values of indexes and their discrepancies for the first six countries listed in the table, although this problem is not limited just to them.

$10 \mathrm{r}=0.79, \mathrm{p}=0.000, \mathrm{n}=18$, one-tailed test. Interpretations should acknowledge that in some instances the number of observed units is relatively small, as for instance in the case of correlation between the CSI and GCSI index, where the results are based on only 6 observations, since the data collection of those two indexes overlaps only for this number of countries.

11 This could be explained by the fact that GCSI measures only the international dimensions of sector development; it is reasonable to expect that those dimensions should be relatively greater in smaller and more open democratic countries, thereby rationally explaining certain discrepancies associated with the GCSI index. 
DRUŠ. ISTRAŽ. ZAGREB GOD. 21 (2012)

BR. $3(117)$

STR. $631-650$

PEVCIN, P.

MEASURING AND..
12 The arguments of market and contract failure are sometimes labelled as trust theory (see Hansmann, 1996). Imperfections in market relationship and informational asymmetry can cause providers to be able to exploit their market position and the ignorance of buyers to maximise their interest (Grønbjerg, 1998). Because civil society organisations have less incentives and possibilities to exploit buyers' ignorance, they are usually more trusted in providing certain goods and services which are characterised by large market imperfections or the existence of important informational asymmetries.

13 Literature, however, stresses that it is necessary to differentiate between the two distinct features of heterogeneity: socio-economic (supply side) heterogeneity and cultural (demand side) heterogeneity. The cultural aspect of heterogeneity (usually described through ethno-linguistic, cultural and religious fragmentation of society) is actually in line with the proposition of heterogeneity theory. In contrast, the effect of socio-economic heterogeneity should be opposite. The idea is that the resources available to civil society organisations are more easily attainable in more socially homogeneous societies where also greater social cohesion exists. This means that the frequency of social interactions also tends to be greater in those societies (Corbin, 1999). See Matsunaga et al. (2010) on the empirical verification of the theory in a cross-national perspective.

14 See Bielefeld (2000) or Luksetich (2008) on the empirical verification of the theory. Moreover, it should be stressed that this government - civil society relationship has been addressed in the social origins theory (Salamon and Anheier, 1998), which argues that the development of the civil society sector is an outcome of power relations between different social classes and key social institutions. In this context, four regime types should be recognised, namely statist, social-democratic, liberal and corporatist regimes, each with different relations between the government and the civil society sector in the provision of "public" goods and services, although some authors suggest that even more regimes could be described (see Kabalo, 2009). To rephrase, the question of social origins approach is whether the government complements or crowds-out civil society organisations in the provision of such services. On the empirical verification of this concept, see, e.g., Young (2000), Salamon and Sokolowski (2001), Kala (2008), Stadelmann-Steffen (2011), etc.

15 See Ben-Ner and van Hoomissen (1992), Corbin (1999) or Grønbjerg and Paarlberg (2001) on the empirical verification of this theory.

16 The majority of existing studies are usually country specific or they are focused on the empirical verification of particular theories. For instance, studies performed by Corbin (1999), Grønbjerg and Paarlberg (2001) or Luksetich (2008) are nationally oriented, whereas studies performed by Salamon and Sokolowski (2001) or Matsunaga et al. (2010) tend to be more oriented towards verifying the validity of a particular theory in a cross-national perspective.

17 For instance, only 18 of the countries included in the GCSI(JH) analysis are also simultaneously included in the GCSI analysis.

18 It needs to be stressed that the research was attempted to be carried out in the largest possible sample of countries. The problem is 
DRUŠ. ISTRAŽ. ZAGREB GOD. 21 (2012), BR. $3(117)$

STR. $631-650$

PEVCIN, P.: MEASURING AND.. also that in some instances the data is also collected for entities that are formally not independent countries (e.g. Wales and Hong Kong in the CSI study, etc.).

19 The study utilises data from 32 countries: Argentina, Australia, Austria, Belgium, Brazil, Colombia, Czech Republic, Finland, France, Germany, Hungary, India, Ireland, Israel, Italy, Japan, Kenya, Mexico, the Netherlands, Norway, Pakistan, Peru, Philippines, Poland, Romania, Slovakia, South Africa, South Korea, Spain, Sweden, United Kingdom and United States.

20 The study utilises data from 37 countries: Argentina, Azerbaijan, Bolivia, Bulgaria, Chile, China, Croatia, Czech Republic, Ecuador, Egypt, Georgia, Germany, Ghana, Greece, Guatemala, Honduras, India, Indonesia, Italy, Jamaica, Lebanon, Macedonia, Mongolia, Mozambique, Nepal, the Netherlands, Nigeria, Poland, Romania, Russia, Slovenia, South Korea, Togo, Turkey, Ukraine, Uruguay and Vietnam.

21 The study utilises data from 33 countries: Argentina, Austria, Belarus, Belgium, Bulgaria, Chile, Croatia, Czech Republic, Denmark, Estonia, Finland, France, Germany, Greece, Hungary, Iceland, Ireland, Italy, Latvia, Lithuania, Luxemburg, Mexico, Netherlands, Poland, Russia, Slovakia, Slovenia, Spain, Sweden, Switzerland, Ukraine, United Kingdom and United States.

22 Although it is difficult to directly investigate the effect of the market failure argument, an insight into the existence of market failure could be indirectly observed through poverty (Corbin, 1999).

23 Nonetheless, a variable describing openness of the country has been added as an explanatory variable in the Global Civil Society Index (GCSI) model, since GCSI includes only those dimensions of the sector that go beyond national borders. In this context, the idea is that the development of civil society should also be related to the openness of the country. Trade relations with other countries (exports and imports in GDP) serve as a proxy for describing the openness of a society as they tend to be used in similar context also in several other economic studies.

24 Since many variables used in the analysis are not collected and reviewed on a regular basis, the focus is more oriented towards the evaluation of the concepts discussed in the paper rather than the issues of data quality.

25 Although several other alternative measures of democracy exist, this index has been taken as a proxy since it covers democratic development of particular society also in longitudinal dimension.

26 It should be stressed that GDP per capita often does not perfectly reflect the wealth and development of society. Namely, several authors state that it does not incorporate all aspects of well-being, as GDP levels do not take into account certain real costs of production because these costs do not pass through markets (Mishan, 1993). Nevertheless, since the resource availability tends to depend on income, GDP per capita should reasonably be used to test this hypothesis.

27 The problem of achieving internationally comparable data on poverty exists in cross-national comparisons. Namely, absolute poverty measures are closely related to the development of society, which 
DRUŠ. ISTRAŽ. ZAGREB GOD. 21 (2012)

BR. $3(117)$

STR. $631-650$

PEVCIN, P.:

MEASURING AND. omits the possibility to associate those levels to the perceived market failure. Besides, data on Head Count Index is biased, since definitions of poverty vary among countries, as wealthier countries tend to employ more generous standards of poverty, and some countries even do not report the official values of index (see World Bank, 2010).

28 Ethnic fragmentation considers not only linguistic but also racial and physical characteristics, which are omitted if only linguistic fragmentation is taken into consideration. This distinction is particularly important for Latin American countries, which tend to be linguistically more homogenous than ethnically. In contrast, linguistic fragmentation has a greater tendency to also reflect ethnic fragmentation in European countries. For more on the reasons for separation of the two measurements of fragmentation see Alesina et al. (2003), although some combined measurements of ethno-linguistic fragmentation have also been developed (see Desmet et al., 2009). Nevertheless, the analysis has shown that combined measurement reflects more on the linguistic fragmentation of a society rather than ethnic fragmentation, so it is also reasonable to use separate measures of fragmentation.

${ }^{29}$ Bivariate Pearson correlation coefficients (one-tailed test); p-values are in parentheses.

30 Value of the correlation coefficient between GCSI and the openness of society is 0.138 , showing a rather weak positive correlation between the two variables. This is in line with theoretical predictions, although the relationship is not statistically significant $(p=0.22)$.

31 It is worth noting that explanatory variables were excluded from the models if statistical tests proved they tend to be redundant variables (according to Chi-square test) deflating adjusted $\mathrm{R}^{2}$ (Gujarati, 2003). Besides, no excessively high correlations between explanatory variables could be observed and all regression models tend to be structurally stable.

32 This could be ascribed to the fact that the CSI measurement is rather "weak" in methodological terms. The analysis was also performed for a very diverse set of countries.

33 Ordinary least squares regression estimation. Log-lin regression functions are estimated except for model 3, where log-linear function is estimated as structural instability of linear and log-linear model could be observed. Standard errors and t-values are in parentheses. T-values include White heteroscedasticity-consistent standard errors $\left({ }^{* *}\right.$ means $\mathrm{p}<0.01 ;{ }^{* *}$ means $\mathrm{p}<0.05 ;{ }^{*}$ means $\left.\mathrm{p}<0.10\right)$.

34 This model also includes a variable openness of the country among explanatory variables. The idea is that the civil society sector extending over national or societal borders depends also on the extent of openness of the society. As expected, the effect is positive (coefficient 0.1682$)$ and also statistically significant at a $5 \%$ margin $(t=2.64)$.

35 Interestingly, in models 1 and 3 ethnic fragmentation negatively affects and linguistic fragmentation positively affects the variations in sector development among countries, whereas it is quite opposite for model 2. A possible explanation could be statistically related to positive correlation between two variables, which causes these overlaps. 
36 A possibility exists, for example, for the CSI index to take four major dimensions as separate sub-measures of sector development, thus enabling an analysis of pooled data in a specific context. This could be recommended for future research.

\section{REFERENCES}

Alesina, A., Devleeschauwer, A., Easterly, W., Kurlat, S. and Wacziarg, R. (2003), Fractionalization. Journal of Economic Growth, 8 (2): 155-194. doi:10.1023/A:1024471506938

Anheier, H., Glasius, M. and Kaldor, M. (eds.) (2001), Global Civil Society 2001, Oxford, Oxford University Press.

Ben-Ner, A. and Van Hoomissen, T. (1992), An Empirical Investigation of the Joint Determination of the Size of the For-Profit, Non-Profit and Voluntary Sectors. Annals of Public and Cooperative Economics, 63 (3): 391-415. doi:10.1111/j.1467-8292.1992.tb02098.x

Bielefeld, W. (2000), Metropolitan Nonprofit Sectors: Findings from the NCCS Data. Nonprofit and Voluntary Sector Quarterly, 29 (2): 298-314. doi: $10.1177 / 0899764000292005$

Chandhoke, N. (2002), The Limits of Global Civil Society. In: M. Glasius, M. Kaldor and H. Anheier (eds.), Global Civil Society 2002 (pp. 35-53), Oxford, Oxford University Press.

CIA (2010), The World Factbook 2010, Washington, Central Intelligence Agency.

Civicus (2006), Civicus Civil Society Index: Preliminary Findings Phase 2003-2005, World Alliance for Citizen Participation.

CNP (2004), The John Hopkins Comparative Nonprofit Sector Project, Baltimore, John Hopkins Center for Civil Society Studies.

Corbin, J. J. (1999), A Study of Factors Influencing the Growth of Nonprofits in Social Services. Nonprofit and Voluntary Sector Quarterly, 28 (3): 296-314. doi:10.1177/0899764099283004

Desmet, K., Ortuño-Ortín, I. and Wacziarg, R. (2009), The Political Economy of Ethnolinguistic Cleavages, NBER Working Paper No. 15360, Cambridge, National Bureau of Economic Research.

Freedom House (2002), Freedom in the World 2002 Report, Washington, Freedom House. http://www.freedomhouse.org (8. 6. 2010)

Glasius, M., Kaldor, M. and Anheier, H. (eds.) (2002), Global Civil Society 2002, Oxford, Oxford University Press.

Grønbjerg, K. A. (1998), Markets, Politics, and Charity: Nonprofits in the Political Economy. In: J. S. Ott (ed.), The Nature of the Nonprofit Sector (pp. 217-231), Boulder, Westview Press, 2001.

Grønbjerg, K. A. and Paarlberg, L. (2001), Community Variations in the Size and Scope of the Nonprofit Sector: Theory and Preliminary Findings. Nonprofit and Voluntary Sector Quarterly, 30 (4): 684-706. doi:10. 1177/0899764001304004

Gujarati, D. (2003), Basic Econometrics, Boston, McGraw-Hill.

Gwartney, J. and Lawson, R. (2009), Economic Freedom of the World: 2009 Annual Report, Vancouver, Fraser Institute. 
DRUŠ. ISTRAŽ. ZAGREB GOD. 21 (2012) BR. 3 (117),

STR. $631-650$

PEVCIN, P.: MEASURING AND.
Hansmann, H. (1996), The Ownership of Enterprise, Cambridge, Harvard University Press.

Howard, M. M. (2002), The Weakness of Postcommunist Civil Society. Journal of Democracy, 13 (1): 157-169. doi:10.1353/jod.2002.0008

Kabalo, P. (2009), A Fifth Nonprofit Regime?: Revisiting Social Origins Theory Using Jewish Associational Life as a New State Model. Nonprofit and Voluntary Sector Quarterly, 38 (4): 627-642. doi:10.1177/ 0899764009333333

Kala, K. (2008), The Social Origins of the Estonian Non-Profit Sector. Trames, 12 (4): 441-449. doi:10.3176/tr.2008.4.05

Lewis, D. (2010), Nongovernmental Organizations, Definition and History. In: H. Anheier and S. Toepler (eds.), Encyclopaedia of Civil Society, 1st Edition, New York, Springer.

Lohmann, R. A. (1992), The Commons, San Francisco, Jossey-Bass.

Lorentzen, H. (2010), Sector Labels. In: R. Taylor (ed.), Third Sector Research (pp. 21-36), New York, Springer.

Luksetich, W. (2008), Government Funding and Nonprofit Organizations. Nonprofit and Voluntary Sector Quarterly, 37 (3): 434-442.

Lyons, M. (2009), Measuring and Comparing Civil Societies. Cosmopolitan Civil Societies Journal, 1 (1): 71-84.

Matsunaga, Y., Yamauchi, N. and Okuyama, N. (2010), What Determines the Size of the Nonprofit Sector?: A Cross-Country Analysis of the Government Failure Theory. Voluntas, 21 (2): 180-201. doi:10.1007/ s11266-010-9125-9

Mishan, E. J. (1993), The Cost of Economic Growth, New York, Praeger Publishers.

Pfeffer, J. and Salancik, G. R. (1978), The External Control of Organisation: A Resource Dependence Perspective, New York, Harper Collins.

Salamon, L. M. (1987), Partners in Public Service: The Scope and Theory of Government-Nonprofit Relations. In: W. W. Powell (ed.), The Nonprofit Sector: A Research Handbook (pp. 99-117), New Haven, Yale University Press.

Salamon, L. M. (1994), The Rise of the Nonprofit Sector. Foreign Affairs, 73 (4): 109-122. doi:10.2307/20046747

Salamon, L. M. (1999), What is the Nonprofit Sector and Why Do We Have It? In: J. S. Ott (ed.), The Nature of the Nonprofit Sector (pp. 162-166), Boulder, Westview Press, 2001.

Salamon, L. M. (2010), Putting the Civil Society Sector on the Economic Map of the World. Annals of Public and Cooperative Economics, 81 (2): 167-210. doi:10.1111/j.1467-8292.2010.00409.x

Salamon, L. M. and Anheier, H. (1998), Social Origins of Civil Society: Explaining the Nonprofit Sector Cross-Nationally. Voluntas, 9 (3): 213-248. doi:10.1023/A:1022058200985

Salamon, L. M., Haddock, M. A., Sokolowski, S. W. and Tice, H. S. (2007), Measuring Civil Society and Volunteering: Initial Findings from Implementation of the UN Handbook on Nonprofit Institutions, Working Paper No. 23, Baltimore, The John Hopkins Center for Civil Society Studies. 
DRUŠ. ISTRAŽ. ZAGREB GOD. 21 (2012), BR. 3 (117)

STR. $631-650$

PEVCIN, P.: MEASURING AND...
Salamon, L. M. and Sokolowski, W. (2001), Volunteering in Cross-National Perspective: Evidence From 24 Countries, Working Paper No. 40, Baltimore, The John Hopkins Center for Civil Society Studies.

Salamon, L. M. and Sokolowski, W. (2004), Global Civil Society: Dimensions of the Nonprofit Sector, Volume Two, Bloomfield, Kumarian Press.

Stadelmann-Steffen, I. (2011), Social Volunteering in Welfare States: Where Crowding Out Should Occur. Political Studies, 59 (1): 135-155. doi:10.1111/j.1467-9248.2010.00838.x

Taylor, R. (2002), Interpreting Global Civil Society. Voluntas, 13 (4): 339-347. doi:10.1023/A:1022046125396

United Nations (2009), Human Development Report, New York, United Nations.

Vanhanen, T. (2000), A New Dataset for Measuring Democracy, 1810-1998. Journal of Peace Research, 37 (2): 251-265. http://www.prio.no (10. 10. 2010, dataset version 2.0)

Weisbrod, B. A. (1988), The Nonprofit Economy, Cambridge, Harvard University Press.

World Bank (2001), World Development Indicators 2001, Washington, World Bank.

World Bank (2010), Poverty \& Inequality Analysis, Washington, World Bank. http://web.worldbank.org (31. 1. 2011)

Worth, M. J. (2009), Nonprofit Management, London, SAGE Publications.

Young, D. R. (1998), Government Failure Theory \& Contract Failure Theory. In: J. S. Ott (ed.), The Nature of the Nonprofit Sector (pp. 190-196), Boulder, Westview Press, 2001.

Young, D. R. (2000), Alternative Models of Government-Nonprofit Sector Relations: Theoretical and International Perspectives. Nonprofit and Voluntary Sector Quarterly, 29 (1): 149-172. doi:10.1177/08997 64000291009

\section{Mjerenje i tumačenje razvoja sektora civilnoga društva}

Primož PEVCIN

Fakultet za upravu, Ljubljana

U zadnjim desetljećima znatno je porasla društveno-ekonomska važnost sektora civilnoga društva. Taj se sektor danas smatra jednim od preduvjeta društvenog $\mathrm{i}$ ekonomskog razvoja društva. Ipak, usporedbom s međunarodnim podacima, otkrivaju se osjetna odstupanja $u$ razvoju i društveno-ekonomskoj važnosti sektora. Rad predstavlja tri moguće vrste mjerenja razvoja civilnoga društva, koje možemo opisati različitim indeksima civilnoga društva. Rezultati upućuju na pozitivnu povezanost alternativnih mjerenja razvoja civilnoga sektora, iako se snaga i značaj tih veza znatno razlikuje. Nadalje, sposobnost 
DRUŠ. ISTRAŽ. ZAGREB GOD. 21 (2012)

BR. 3 (117),

STR. $631-650$

PEVCIN, P.:

MEASURING AND. empirijskoga tumačenja odstupanja u razvoju civilnoga sektora interpretacijama teorijski uvjerliivih ekonomskih, političkih, društvenih i kulturnih varijabli ovisi o odabiru načina mierenja razvoja civilnoga društva. No čini se da empirijski rezultati upućuju na to da su upravo razlike u kulturnoj fragmentaciji i bogatstvu društva relevantni čimbenici bez obzira na razmatrani indeks civilnoga društva.

Ključne riječi: sektor civilnoga društva, značajke sekłora, indeksi civilnoga društva, razlike, empirijska analiza 